\title{
Constructing a Native Consciousness: Taiwan Literature in the 20th Century
}

\author{
Angelina C. Yee
}

Few notions in the contemporary world elicit such public demonstration and widespread passion as that of the nation. Even at the end of the 20th century, national conflagrations from Kosovo to East Timor still seize headlines from global treaties and space explorations. While scholars argue that the nation is intersubjectively imagined, discursively produced, and "narrated" and "performed" out of shreds and fragments, the notion, far from being an outmoded concept, shows every sign of gathering strength, intertwined with and supplanting deep-seated religious beliefs and social progress as a sanctified norm. ${ }^{1}$ Between the local, the national and the supranational whose demarcations are themselves contested, various discursive strands intersect and dispute, vying to redraw maps or rewrite histories. The terrifying devastation allegiance to different nations can unleash therefore weighs heavily on a retrospective on Taiwan, in a double bind of dispassion and engagement. The subject is a particularly sensitive one, for the very invocation of the name "Taiwan," depending on its context, manner and intonation, implicates particular ideological stances. For those living in Taiwan and across the Strait, the name is more than a geopolitical construct; it is a transcendental signifier fraught with emotional meaning. In literature and the arts, the relatively brief history of representing Taiwan's trials and tribulations has already assumed mythical proportions, evoking a landscape of sorrow, subjugation and destitution. To many, the people of Taiwan have long been subjected to a succession of colonizers' myths that deny their existence and obliterate their local histories in subservience to grand national narratives. The task of self-redefinition, of reconstructing a history and a cultural identity distinct from an increasingly overpowering mainland China has become for many an urgent moral imperative. Such re-scripting of self-identity and relations with the ancestral homeland brings interesting insights to bear on postcolonial narratives; it also offers powerful illustration of the agency of cultural discourses in making and unmaking communities. In more practical terms, the construction of a native consciousness in literature and the arts has buttressed a popular sentiment for recognition - recognition, if not of Taiwan as an independent state, then of the people's lived presence, and of the vital and distinct role they play in world affairs.

For those attached to the notion of the Han people as an integral nation, however, such a development is particularly disturbing. China, conventionally characterized as long possessing a continuous, homogeneous

1. For theoretical discussions of the nation, see especially Benedict Andersen, Imagined Communities (London: Verso, 1991); Ernest Gellner, Nations and Nationalism (Ithaca: Cornell University Press, 1983); Eric Hobsbawm and Terence Ranger (eds.), The Invention of Tradition (Cambridge: Cambridge University Press, 1992); and Homi K. Bhabha (ed.), Nation and Narration (London: Routledge, 1990).

(C) The China Quarterly, 2001 
civilization, has hitherto stood as a proud exemplar of the perdurance of cultural identity enshrined by the nation-state. To Chinese nationalists, the modern understanding of nationhood finds correlatives in age-old historiographical discourse: references to $\min$ (subjects/people), bang (fiefdom/state), tianxia (all lands and peoples under heaven), the Han race and the superiority of Han Chinese culture have long been canonized in state ideology and inscribed in popular lore. Such a complex of racial, national and cultural identity is conflated into a map of the modern Chinese nation-state with Taiwan as an integral part. And the prime ethic of allegiance to a central ruling authority reaches far back in official versions of collective memory. Thus it is all the more traumatic when China's vitality as a unified entity is challenged physically or intellectually. Furthermore, for those who have endured their share of imperialist invasion on the mainland, it is difficult to see Taiwan's colonial history as separate or antagonistic.

The story of Taiwan is told with many beginnings, their temporal and spatial configuration largely a function of the narrators' end. While historians implicitly agree on one period marker, that modern Taiwan begins with Japanese colonial rule (1895-1945), the representations of Taiwan's colonial legacy are diametrically opposed; it is a period construed either as the origin of cultural difference from the mainland, or as proof of continued national allegiance. Both the narratives of difference and sameness, enmeshed as they are in issues of progress, democracy and political programmes, seek legitimation in re-imagining history, ethnicity and a mythical destiny. Thus the literary writings of Taiwan during Japanese rule have emerged as a bitterly contested site of identity politics, assuming significance far beyond the disciplinary bounds of literary history. And whether as heroic resistance epic or as woeful colonial tragedy, both modes of storytelling give short shrift to the conflicting individual psyche evidenced in literary texts.

This article, rather than attempting a comprehensive survey, shows how at different stages Taiwan writers, in their portrayals of the place and themselves, negotiate between various imagined homelands and competing cultural authorities. Between the complex politics of reading, writing and their mutual entanglement in the production of literary history, it is difficult to pinpoint with any precision the genesis of a native consciousness. The self-representations of their emotional landscape reveal sentiments far more chaotic than either independence or unification discourses would admit. Rather than endorsing or critiquing any particular political programme, the article studies the constructions and manipulations of meanings in particular historical circumstances. Such a process is not merely of theoretical interest; it is being enacted in very human terms, as the tumultuous shifts in the past century - physical, psychological and cultural - have shown.

\section{Defining "Native Consciousness"}

The need to seek a native consciousness bespeaks a lack, not of 
material resources, but of psychological belonging to a defined land. Staking territorial claims itself is not sufficient to build a community; it is necessary to create a history and culture that is uniquely one's own. The engendering of a sense of belonging entails an ongoing, interactive process that implicates constant modifications in definition, infusions and disruptions of meaning, reinterpretations of the past, inventions of customs, and negotiations of boundaries. Put differently, cultural identity is constructed in a dynamic process of intersubjective reinforcement through inculcation, memory and imagination, built on the desire for communal belonging, bolstered by social organization and intervened by contingent historical events.

In the case of Taiwan with its particular colonial history, native consciousness has never simply signified attachment to one's homeland. It is a sense of place defined against the people's loss of identity on the one hand, and against real or imagined encroachments of hegemonic powers on the other. Implicit in such a demand is recovery of loss, redress of injustice, restoration of equality and self-determination of values. Absolute in its demand but limited in fact in available cultural resources, the nativist imagination entails the drawing of physical and historical boundaries as well as an economy of psychological and emotional investment and return. Cultural production, of which literature is but one form, is such an investment and outcome - it is both agent and product of that consciousness. But consciousness or cultural identity defined against a reigning authority does not necessarily entail a desire for political independence, which requires belief in an alternative power structure. On the other hand, to say that a native consciousness or cultural identity is produced, constructed or consciously fashioned is in no way a denigration of independence goals; it is merely an example of the process by which nations come into being.

A native consciousness now so solidly in place where it was lacking in recent memory invites intriguing questions: where, when, how and why did it all begin? Independence discourse generally attributes Taiwan's essential difference from the mainland to the 50-year Japanese colonial rule, if not earlier, and locates a nascent native consciousness in that period. It is therefore important to revisit the texts and contexts of that period, to investigate the ways in which writers positioned themselves between various geopolitical and cultural locations of identities: their ancestral nostalgia, their Japanese acculturation and their effort at imagining alternative ideals. In particular, the diverse responses to imperialist strategies of conquest and assimilation raise the following questions: what does the 50-year colonial period reveal about the colonization of consciousness and the interplay between cultural, national and self identities? When Japanese orientalist discourse was superimposed on the Chinese nationalist discourse, and when current reconstructions of history are enmeshed in political appropriations of colonial writings, is it possible to trace the psychological fragmentation, accommodation and resistance that colonial subjects underwent? What happens to the individual consciousness when the racial markers between the colonizer and colonized 
are blurred, when the claims of a culture both shared and superior seemed plausible, thus making possible not just mimicry, but confusion and even substitution of identities? And more importantly, how do past colonial writings interweave with present-day public discourses in the different constructions of native identity?

\section{The Originary Loss}

The story of colonialism is often told in terms either of conquest and resistance, or of self-glorification and self-abjection. An examination of Taiwan's colonial period will show a picture far more complex. Japan's grandiose mission to save itself and East Asia from a degenerate China on the one hand and from a militant and morally decadent West on the other was particularly seductive. ${ }^{2}$ Therefore the unisonance of protests against its colonization recaptured in hindsight simplifies far more chaotic sentiments on the part of the colonial peoples.

The occupation of Taiwan by Japan, recorded triumphantly in the annals of Japanese imperialists and footnoted to Manchu corruption by Chinese official narratives, had long been submerged by the tide of communist victory. It was not until the 1980s that colonial texts re-surfaced to any appreciable extent, but since then a dramatic reversal has occurred. First and second generation writers such as Lai He (1894-1943), Wu Zhuoliu (1900-76) and Yang Kui (1905-85) have been re-discovered and erected on rival altars: either as successors to the mainland's anti-imperialist struggle, or as progenitors of a native Taiwan literature. Aesthetes who, in the face of increasing censorship, wrote for art's sake in the 1930s and 1940s, among them Zhang Wenhuan (1909-78), Long Yingzong (1911-?), Weng Nao (1908-39), Wang Changxiong (1916-?) and Wu Yongfu (1913-?), once shunned as insufficiently anti-colonial, have been elevated to the pantheon of first-generation nativist writers. Japanese culture, decried after Taiwan's retrocession, has now gained pre-eminence as a fountain of Taiwan culture.

But the mood of colonial writers was seldom celebratory and rarely heroic at the time. As Albert Memmi has described, the bond between the colonizer and the colonized is both destructive and creative. ${ }^{3}$ Among the Taiwan petty-bourgeois intellectual, there were varying degrees of alienation and assimilation with the Japanese, of identity with an ancestral link with China, and of desire to create a native consciousness. What complicates the picture is the problem presented by linguistic gaps: between written Chinese, in which the older generation was trained, the local vernaculars (mainly minnan and hakka), and the official language, Japanese, in which the second and third generation writers were schooled. Towards the war years, with the intensification of the kominka movement, Japanese became the only publishable one. During the 1920s, it was still

2. Stefan Tanaka, Japan's Orient (Berkeley: University of California Press, 1993).

3. Albert Memmi, The Colonizer and the Colonized (New York: Orion Press, 1965). 
possible for some, such as Lai He, Chen Xugu (1896-1965), Cai Qiutong (1900-?) and Wu Zhuoliu, to excoriate the colonizer by varying modes of protest and satire in none-too elegant Japanese and Chinese. ${ }^{4}$ It was in response to the linguistic quandary that some experimented with the creation of a local written vernacular, a movement that became smothered by calls led by the prominent intellectual, Zhang Wojun (1902-55), to carry on the May Fourth tradition in Taiwan. ${ }^{5}$ As Japanese acculturation began to take root, however, an entire generation grew up with no knowledge of spoken or written mandarin. While some literary historians gloat over the handful of Japanese-educated writers who won prizes for their publications in Japan - Yang Kui (1905-85), Lu Heruo (1914-47), Zhang Wenhuan and Long Yingzong, for example - others bemoan the lack of a mother tongue. The moment one begins to write in the colonizer's language, the question is raised of whom one is writing for, and what effect such hybridization, whether intentional or subconscious, has on the construction of meaning between writer and reader. Does the very act of writing condemn the self and his kin to a position of servitude? How could the historian assess the psychological violence inflicted through such linguistic subservience? If "speaking" itself is already over-determined by the structure and history of domination, is it possible to speak or indeed to imagine an outside to the colonizer's linguistic and epistemological frame? In sum: how can one speak of creating a pure "native" consciousness under colonial domination?

What immediately strikes the reader of these colonial writings are the overall subdued tone, the amount of remorseful introspection, the schizophrenic disjunction between self and other, and the profound sense of lack or loss. Such a sense of deprivation is best captured by the title of Wu Zhuoliu's novel, Yaxiya de gu'er (Asia's Orphan - 1945), which has since become the defining symbol for Taiwan's homeless plight. The novel, written in secret in Chinese during the colonial era and published after the war, surveys through an intellectual's sensitive eyes the material hardship and spiritual decay wrought by colonial rule and imperialist war. Unable either to identify with the Japanese colonialists or to bear with his traditional family and regressive hometown, he smuggles himself to the mainland in the hope of finding succour, only to be disdained as a Taiwanese and suspected of being a Japanese spy. A similar fate awaits him when he returns to Taiwan. Disowned by the cultural metropole, the ancestral homeland and his native land, the distraught $\mathrm{Hu}$ Taiming eventually goes mad. The story ends with a poem the demented $\mathrm{Hu}$

4. Li Nan-heng (ed.), Riju xia Taiwan xin wenxue: wenxian ziliao xuanji (New Taiwan Literature of Taiwan under Japanese Occupation: Selected Documents and Materials) (Taipei: Mingtan, 1979); Ye Shitao, Taiwan wenxue shigang (An Outline of Taiwan Literary History) (Kaohsiung: Wenxuejie, 1991) and Zouxiang Taiwan wenxue (Towards a Taiwan Literature) (Taipei: Zili wanpao, 1990); Xu Junya, Taiwan wenxue lun (On Taiwan Literature) (Taipei: Nantian, 1997).

5. Zhang Wojun shiwen ji (Collected Poems and Essays of Zhang Wojun) (Taipei: Chun wenxue, 1989). 
scribbles on the wall that must have fired patriotic fury when the novel was first published, but that cannot but ring with irony when read today:

Willing to be educated intellectuals,

How could we stoop to be downtrodden people?

Where are the axes for slaying tyrants?

Dreams full of heroes.

Our Han soul shall never die,

Defiantly we shed this body.

"Foxy, foxy!"6

What do you want?

A slave's life is full of remorse.

When despots reign, what to do?

Together let's recover our ancestral land,

Six million people, rise!

Vow to die a righteous death!

Invoking the "Han soul" of the "six million" inhabitants on Taiwan, it is one of the first formulations of an abandoned community cornered into self-redemption. ${ }^{7}$

Writing 20 years before in Japanese, Yang Kui, whose creative life spanned the colonial period and after the retrocession and who won nearly unanimous praise for his staunch anti-colonial stand, reveals nevertheless some of the ambiguities surrounding self and national identities. Carefully navigating between an affable Japanese culture and an invisible colonial government, Yang also writes of a Taiwanese student's bittersweet experience in Japan in a prize-winning story, "Songbaofu" ("The newspaper boy" - 1932). ${ }^{8}$ The narrative of exploitation of foreign students by a Japanese capitalist is counterbalanced by that of his friendship with a kind, upright Japanese co-worker; what began with nationalist indignation turns into a socialist paean to transnational fraternity. The revealing part of the story occurs when he receives news of his mother's illness and vacillates about leaving Japan. Though in the end he decides to return home, he had been loathe to leave Tokyo, and his memories of home had been dreary. Thus the ending - his hero's welcome as a proletarian fighter - is fraught with unintended irony. Later, during the war years when the kōminka movement raged, Yang succumbed to the pressure and exhibited an even more pronounced ambivalence toward the metropole and the native. In "Zengchan zhi beihou lao choujiao de gushi" ("Behind increased production - the story of the old fool" - 1944), which paints an idyllic picture of miners eagerly stepping up production to support Japan's war effort, Yang holds up as a paragon of virtue a Japanese old man who nurtures a Taiwanese girl into perfect femininity. ${ }^{9}$ Such idealization of Japanese tutelage is consist-

6. A disparaging term the Japanese used on the Taiwanese.

7. Taipei: Yuanjin, 1993, pp. 278-79.

8. Yang Kui ji (Collected Works of Yang Kui) (Taipei: Qianwei, 1991), pp. 15-58.

9. Ibid. pp. 161-206. 
ent with his description of political awakening via Japanese friends in "Songbaofu," bespeaking his deep admiration for Japanese culture.

Yang was indeed among the first to stake his battlefield on his native soil, but what he ultimately articulates is the celebration of individual will rather than a collective native consciousness. The affirmation of the lonely fighter is a leitmotif that recurs in his writings towards the war years, and, probably owing to censorship, his style became increasingly lyrical and self-allegorical. These include "Wuyi cun" ("Doctorless village" - 1942) - the doctor who turns to poetry when he realizes that medicine is impotent in the face of poverty and death; "Ni wawa" ("Clay dolls" - 1942); "Shouyang yuan zaji" ("Miscellaneous notes of Shouyang garden" - 194?); "Woyou yi kuai zhuan" ("I have a brick" - 194?). His self-exhortation to resist tyranny continues into his 12 -year incarceration by the KMT regime on Lü Dao (Green Island), as essays and letters he wrote in that period will attest. In "Ya bu bian de meigui" ("Uncrushable rose" - 1957), he uses the lone rose to pay tribute to the irrepressible yearning for individual freedom. While the spirit never dies, the image is solitary, and his gardening both in writing and in practice becomes emblematic of his struggle for self-cultivation.

What is important to note in the foregoing is not Yang's foibles; in any case it is impossible to ascertain whether the komin pieces were written to appease the colonial authorities or for self-edification. Rather, as one traces his psychological shifts through his writings, it is instructive to witness the violence brought upon the individual consciousness by colonial and authoritarian rule, even in one as persevering as Yang. Following his metaphorical voyage from a sea of battle in "Songbaofu" to the Shouyang Garden - head uplifted - to the rose, one sees analogous shifts from nationalism to internationalism and individualism, although the three strands are always interwoven. The last image, the individual fighting the enemy from within, may yet allegorize the political struggle at home. This means that the native consciousness that Yang has reputedly wrought is not simply defined against other nations, but one enormously complicated by questions of class, culture and ideology. ${ }^{10}$

One of the most intriguing explorations of the problematics of self and national identity is found in the novella, Benliu (Raging - 1942), written in Japanese by Wang Changxiong. On the surface a crude national allegory, the real interest of the story lies in the vicissitudes of the narrator's self-discovery. Speaking from the position of a native, the narrator expresses secret admiration for a Taiwanese teacher, whose "sparkling eyes and glowing face" distinguish him from other native islanders. The proud display of his Japanification implicitly contrasts the natives' unease with their colonized condition, and points ironically at the author's own shameful use of Japanese in writing the text:

I was magnetized ... Picture this: an islander who married Japanese, who had become

10. See Angelina Yee, "Writing the colonial self: Yang Kui's texts of resistance and national identity," Chinese Literature: Essays, Articles, Reviews, No. 17, pp. 111-132. 
completely Japanese in speech and manner, standing at the lectern in middle school, proudly teaching the national language (Japanese) ... There he was, sowing the ancient samurai spirit. As I watched, an inexplicable emotion, not exactly joyous but quite intangible, suddenly overcame my entire being, my soul ... All the loneliness and ennui I had felt coming here from the north [Japan] was dispelled. ${ }^{11}$

The larger-than-life Taiwanese with a Japanese name, Itō, culls forth other primal yearnings for female love, true beauty and human worth; these desires conjoin in a Japanese woman who excels in the art of flower arrangement, a metonym for Japanese feminine culture. The textual symmetry is neatly contrived: just as Itō represents perfected masculinity, the Japanese woman epitomizes ideal femininity: "she who enlightens my soul infinitely ... is my teacher, friend, love object." Hence the title Benliu - a raging torrent - becomes a self-reflexive metaphor for the narrator's surging passion for Japanese culture's sublimating beauty. Moreover, such adulation is accompanied by the narrator's feeling of shame at his own "immaturity," as he doubts whether he is worthy of her, or whether it would be fitting to relocate such a perfect creature to the remote backwaters of Taiwan.

Soon the silent observer finds himself watching Itō through the reproachful eyes of Bonian, a native student who resents Itō's disdain of his own biological mother while living with his Japanese mother-in-law. A stormy confrontation between Itō and his mother exposes his ingratitude, triggering in the admiring narrator a crisis of consciousness. This results in a shift in the locus of his alter ego, from Japanified Ito to the native Bonian. The story's deliberate juxtaposition of the colonial versus the native mother points to the national and cultural conflict seething at the diegetic seams. In the end, the tensions between native allegiance and Japanese assimilation arrive at a curious compromise: Bonian vows to master samurai sword-fighting in Japan for the ultimate purpose of serving his native place. But his real weapon, his "only weapon," is the power of "simple youth," as he writes from Japan.

Yes, henceforth I must be a Taiwanese who stands tall. We needn't despise ourselves because we were born in the south [Taiwan]. To assimilate into life here [in Japan] does not mean we must despise the stench of our own native soil. Even if my mother were an unsightly aborigine, I would still remember her with infinite love; if my mother were to show her ill-favoured face here, I would not feel any embarrassment or shame. I would let her embrace me, like a child, naturally.

Transferring filial piety on to love of the homeland, Bonian's nativism is grafted on to a curious mixture of Japanese masculinity, sheer youthful energy and a return to childlike innocence. The irony is that, unbeknownst to Bonian, his study in Japan is financially sponsored by Itō, whom he had condemned.

What is remarkable about this story is not its reconciliation of incon-

11. In Weng Nao, Wu Yongfu, Wang Changxiong heji (Combined Collected Works) (Taipei: Qianwei, 1991), pp. 330-31. 
gruities, which could be understood as a symptom of subjugation to colonialist propaganda, but its tortuous rationalization of such a reluctant choice. In the end, the narrator is poised to embrace Bonian's patchy, enigmatic solution, which awakens him to the beauty of his homeland. The following scene towards the end unfolds a spectacle of the narrator's complex psychology:

Sitting on the meadow ... I could see the distant Taiwan Strait spread desolately before me. The blue sea merged into the blue sky, as if the tiniest breath of air would take on its colour. The deserted harbour, once eulogized as the cultural origin and trading port of Taiwan from time immemorial, now slept quietly in the cradle of spring-hued mother nature. An indescribable feeling crept upon me, as if I was tied to some great, age-old, unintelligible being. Coming into contact with these mountain woods and meadows and the dazzling sunlight in the blue sky, I could feel the distinct palpitation of life. Japan's clear winter had stamped an indelible imprint in my heart, and it suddenly dawned on me that I had forgotten the splendour of my native land's eternal summer. No, I had not loved my native soil enough.

The primordial cultural origin across the Taiwan Strait, now "asleep," is an oblique reference to the dormant mainland relegated to the past, whereas palpable life is here and now in Taiwan. Such an awakening also arouses in him compassion for the radical Itō who has forsaken his mother. The story ends with a cryptic question: "In this era, in order to secure liberation from our deep-rooted vices, should we not conquer them resolutely with our lives, thereby allowing the next generation to internalize [Japanese values] as their own?" The trilemma facing the narrator, then, appears to be that between cultural origin, native "vices" and colonialist "virtue." Rather than arguing an anti-colonialist stand or a filial return, the story voices a desperate plea to accept assimilation for the sake of one's own land, at the cost of conscious self-denial. As such, the piece articulates the intellectual's deep anguish at his own multiple psychic splits: assuming the colonizer's values with a guilty conscience, endeavouring to love one's land in all its glory and ugliness, and abandoning mainland China's forgotten culture.

An earlier story often cited as one signalling the birth of a "Taiwan" or native consciousness is Long Yingzong's "Zhiyou muguashu de xiaozhen" ("Town planted with papaya trees"), published in 1937. Here the narrator's alter ego is Chen Yousan, an aspiring law student who takes up a clerical job in a dreary town. He finds himself embroiled in a small world that is nothing but a dank, dark and dirty "swamp." $\mathrm{He}$ despises the townspeople, a "miserly, uncultivated, vulgar, filthy lot": "old women with bound feet who would quarrel and glower over a penny," "deceptive, contentious, cunning businessmen who never spare a penny, yet borrow extravagantly for weddings and funerals," whose only relief in life is drinking and whoring. And yet, he ruefully reflects, "they stubbornly cling to life, like wild grass flourishing between cracks." $\mathrm{He}$ observes the stark contrast between the natives' cramped, squalid quarters and the Japanese section neatly lined with papaya trees that symbolize the 
social and economic divide. To work hard, to save money to move across the divide and to live among the Japanese is every native's dream. Chen's only hope of transcendence is to marry a Japanese woman: he would "give up 20 years of his life" for the luxury of possessing such a "submissive, cultivated, beautiful bride," if only he could afford her. Over the background of this scenario, however, hover the haunting strains of an ancient Chinese elegy, played plaintively by a beautiful girl whom he espies from across trees. When he does fall in love with a native girl, her father, following the native tradition, insists on waiting for a higher bidder. He soon realizes that romantic frustration is a luxury he can ill afford.

Continuing this musical strain, Chen decides that the age in which he lives is one of "opposing tunes," a time without future, waiting for a miracle. Threatened with being dragged into the mud-pool by the general indolence and yet thirsting for new knowledge - a knowledge that would entail self-repudiation - he could not find a "harmonious self." The story concludes with the despairing image of his lover's father gone mad, "with tattered clothes, dishevelled hair and lifeless eyes, clasping his dirty hands, uttering an inarticulate prayer to unnamed gods." ${ }^{\prime 2}$

In another essay, Long complains of his fatigue in his quest for identity: he "longs to slip into an easy chair and fall into a century-old slumber." 13

To sum up, I would argue that few of the literary writings in the Japanese occupation might be characterized as directly or simply anticolonial. The picture painted by Taiwan writers during the 1930s and 1940s is a complex, variegated one. If there is despair and shame at the poor, ignorant country, there is also profound longing for the progressive, sophisticated metropole represented by Japan. The effort by some writers to make peace by recourse to transcendental love or transnational fraternity resulted in some moving testimony to internal struggles and eventual capitulation. While some tried to justify their emulation of Japanese culture in the name of self-betterment and social progress, others threw themselves into a tangible test of manhood by heroic resolve to join the Imperial Army in hopes of creating a better "Oriental" world. None seemed able to offer a coherent picture of a national past, an imagined community unsullied by foreign domination, or a beckoning future of national pride and unity. Hence much of the writing is ahistorical, locating cultural memory in unnamed times and places before the Japanese colonial presence, before the ancestral landing on the island, and before the loss of innocence. Example of such mythic parables are Zhang Wenhuan's "Yeyuan" ("Night apes" - 1942), in which a family of mountain dwellers is implicitly compared to apes clinging on to their mother for survival; Long Yingzong's "Mo" ("Monkeys"-1941) and "Baise de

12. Long Yingzong ji (Collected Works of Long Yingzong) (Taipei: Qianwei, 1991), pp. $13-72$.

13. "Redai de yizi," (“Tropical chair”), Wenyi Shoudu (Arts and Literary Metropolis), Vol. 9, No. 3 (April 1941), pp. 95-96. 
shanmai" ("The white mountain chain" - 1941). ${ }^{14}$ The period is redolent with tales of blighted love and economic woe, of lack of meaning in life and longing for belonging. The creation of a literal third space - the shaping of a Taiwan consciousness - is a quixotic dream few writers relished at the time.

\section{Garden Twice Lost-Literature after the Retrocession}

The garden (yuan) image, together with its cognates jiayuan, tianyuan, leyuan, connecting on several semiotic levels to the family, the nation and utopia, is one that Yang Kui exploited effectively to signify his commitment to native soil. In his hands the garden harks back to ancient China, to the Zhou dynasty when the brothers Bo Yi and Shu Qi escaped to Mount Shouyang rather than collaborate with the new regime. ${ }^{15}$ Thus it is a symbolic space whose meaning remains to be created by individual striving. The metaphor's repeated use is symptomatic of an age in which self, family and national identities are continually imperilled. As an entire generation of Taiwan writers had grown up without any knowledge of Chinese, and since Japanese was banned soon after Taiwan's retrocession, the literature of Taiwan during the 1950s and 1960s is dominated by mainland emigres obsessed with their past homeland. To Bai Xianyong (1937-), a mainlander who emigrated to Taiwan after 1945, the garden is a lost paradise impossibly transposed. His celebrated Taibeiren (Taipei People) is a gallery of portraits of dislocated mainlanders nostalgically re-enacting their former days of glory on the mainland, as if in a trance. They throw the same parties, observe the same rituals, wear the same clothes, sing the same tunes, flirt with the same lovers, address their superiors by the same official titles now defunct, and, in one instance, the mistress of the party even stays looking exactly the same, frozen in time. Nothing has changed for these erstwhile aristocrats except that they have lost a whole kingdom. The irony is that these mainlanders are living in a dreamland that they compulsively attempt to re-create. Remembrances of past grandeur can only cast umbrage on present diminution; artificial transposition of space and time can only self-implode. Thus Taibeiren, rather than being a collection of short stories, is a self-conscious satire about artifice, and as such constitutes a crushing critique of mainlanders' lost sense of time and space. ${ }^{16}$

A contemporary of Bai's, Chen Yingzhen (1937-), though initially grouped with nativist writers for his depiction of village life threatened by commercial encroachment, is in fact most adept at portraying the conflicted psychology of the intellectual - the brooding, self-doubting man who, with the loss of everything of value on the mainland, has failed to recapture any meaning in his transplanted life in Taiwan. In "Diyijian

14. Zhang Wenhuan ji (Collected Works of Zhang Wenhuan) (Taipei: Qianwei, 1991), pp. 135-178; Long Yingzong, "Shanmai," Wenyi Taiwan, Vol. 3, No. 1 (October 1941) and "Mo," Riben fengsu (Japanese Lifestyle).

15. Yangtou ji (Goat's Head Essays) (Taipei: Huihuan, 1978).

16. Taibeiren (Taipei People) (Taipei: Chenzhong, 1973). 
chaishi" ("The first job" - 1967), a policeman charged with investigating a suicide case begins to build up a profile of the deceased. Although the mystery of why he killed himself is never completely solved, the forlorn picture of the well-built man in the prime of life bouncing a basketball alone before committing suicide draws attention to the conspicuous absence of his teammates and the game. The repetitive motion conveys the monotony of life for one who has outlived his usefulness with the loss of his homeland. The circumscribed basketball court with its narrowly defined goal becomes another diminished version of the far larger battlefield mainlanders were forced to desert. ${ }^{17}$

To the nativists who flourished in the 1960s and 1970s, however, Bai's - and, to a lesser degree, Chen's - lamentations must have seemed an extravagant whimper. Because class division was conjoined with the mainlander/islander dichotomy when mainlanders monopolized the power structure, a native awareness of place and belonging brought in its train a sympathy for the politically oppressed and economically deprived. That was why the KMT saw the seeds of subversion in what began as a literary movement, and moved to suppress it. But the nativist movement in its initial stage was a reaction against the modernist school of writing, which in its mimicry of Western techniques was thought to be symptomatic of cultural colonization and an exile psychology. Relying instead on observations of the life of humble folk closer to home, nativists sought above all to create an attachment to the land, to re-embrace soil abandoned by others as one's own, and to resist the degradation of rural life by urbanization, commercialization and foreign capital. It was therefore mainly anti-imperialist and largely anti-capitalist. Government measures to contain this literary trend only provoked further politicization of the movement and split the writers into opposing camps.

Prime examples of the nativists' depiction of social injustice and corruption brought by foreign economic dominance, cultural invasion and capitalist exploitation can be found in works such as "Yuanjia" ("Starcrossed"), "Gongchang ren" ("The factory worker") and "Zai shinan" ("Homegrown boy") by Yang Qingchu (1940-); "Jinshui shen" ("Aunt Jinshui") by Wang To (1944-); "Luo" ("Cymbal"); "Sayonara! Zaijian" ("Sayonara, good-bye") and "Xianggelila" ("Shangrila") by Huang Chunming (1939-). The most memorable statement for the construction of a nativist return to roots is made by Huang in "Kanhai de rizi" ("Days of gazing at the sea" - 1967), in which a long-suffering prostitute decides to regain self-respect by turning her despised trade to her advantage. She chooses the seaman by whom she would be impregnated and, flouting tradition, gives birth to the baby in her hometown, leaving the father of her child behind. With her industry, intelligence and optimism, she helps lift the villagers out of their misery and begins to rebuild her communal life, thereby winning their gratitude and respect. In the end, she takes her son to the seaside, which had inspired her motherhood, and shows him 
where his progenitor once sailed. The repeated childlike songs of the sea compose the story's allegorical frame, juxtaposing the mystery of absent father-sea with the solidity of present mother-earth. Though the metaphor of maternal sanctity is conservative, the woman's silent ordeal and ultimate triumph is portrayed with a straightforward simplicity that is powerfully moving. The author's allegorical solution to Taiwan's national quandary has become synonymous with nativism, an exhortation to the natives to plant and cherish their seeds in their own garden, however bastardized, and from the labour of their hands bring about their own rebirth. $^{18}$

Another writer, Wang Zhenhe (1937-), creates a different kind of nativist consciousness through linguistic and stylistic innovation. Though writers during the colonial period had made abortive attempts to forge a written language based on the vernacular, it was Wang who first succeeded in naturalizing and localizing his fictional world. His "Jiazhuang yi niuche" ("Oxcart for a dowry") is a sardonic dark comedy of a destitute rural couple distinguished only by sadly ludicrous flaws: the man is stone deaf and has a peculiarly repulsive armpit odour, and the woman is flat as a scrubbing board. The interplay between the couple and a vagabond who starts rooming with them and bedding the woman develops like an absurdist play: the farmer decides to barter his wife's weekly trysts for an oxcart. Cast in the satiric mode, the story asks some poignant fundamental questions: what happens when people struggling for mere subsistence are thrown together in a godforsaken land? When it is a matter of survival, what happens to venerated cultural notions such as pride, dignity, love and honour? The story is both ruthless and sympathetic. A complex parable of survival and the human condition, it may also be understood as a bleak portrayal of the loss of human dignity in commercialized rural Taiwan. ${ }^{19}$

A less subtle indictment of Taiwan society's subservience to American hegemony is found in another satirical parable by Wang Zhenhe, Meigui meigui wo ai ni (Rose, Rose, I Love You). Based on the title of a popular song of the 1930s, the central metaphor of roses in a garden refers at once to sexual love - in this case that practised between American soldiers and local prostitutes - and to the nickname of a strand of venereal disease rampant among American soldiers in Vietnam at the time, "Saigon Rose." Most ironically, the metaphoric rose garden is "cultivated" by an intellectual, who, in a farcical mimicry of Professor Higgins' missionary zeal in Bernard Shaw's Pygmalion, spares no pains in preparing the select prostitutes for an appropriately dignified and seductive reception of their American clients. Their hilarious training session is inaugurated in a garden adjoining a forsaken chapel next to a dung-hole, preceded by a Christian mass. The story, ending with the successful embrace between the GIs and the prostitutes in a cacophony of the lustful title song and the

18. Ge Haowen [Howard Goldblatt] (ed.), Хiazi Аmи (Blind Man Аmи) (Hong Kong: Literary Trend Press, 1988), pp. 35-79.

19. Jiazhuang yi niuche (Taipei: Hongfan, 1993), pp. 71-98. 
solemn last words of the Lord's Prayer, takes to task those intellectuals who abet cultural imperialism in pursuit of economic gain. In a broader context, Meigui is a scathing commentary on the moral degradation of Taiwan under imperialist and capitalist invasion. ${ }^{20}$

\section{Loss, Recovery and Reconstruction}

With the government crackdown on the nativist literary movement that began to sound dangerously like the communists' "proletarian literature," Taiwan intellectuals became increasingly polarized. Many were politicized with the Diaoyutai movement in the 1970s, a spin-off from the anti-Vietnam War movement, and radicalized by the Meilidao Incident of 1979; while some looked to the socialist government in Beijing as the source of inspiration, others sought alternatives to KMT repression in different political alliances. With the relaxation of cultural policies in the 1980s and the repeal of martial law in 1987, literary and cultural activity in Taiwan saw an efflorescence of emotional display. International isolation in the wake of U.S. recognition of the PRC presented a glaring discrepancy with the people's pride in Taiwan's economic miracle, and increased traffic to the mainland deepened the psychological rift with mainland politics, economic reality and cultural repression. The movement to create a native Taiwan consciousness, long suspect in the eyes of the ruling regime, gathered force and has by now, with the native Lee Teng-Hui and Chen Shui-bian at the helm, become a dominant discourse in the public domain. A flurry of activities to commemorate the 28 February Incident, including dramatizations, histories, concerts, memorials and monuments, has fuelled heightened emotions and the institutionalization of 28 February into a new marker of the birth of the Taiwan nation. In the realm of literature, the garden that is Taiwan is artistically recapitulated with the addition of new twists.

A look at Li Qiao's (1934-) literary experimentation will serve to demonstrate one intellectual trend in the past two decades. Beginning with explorations of the Freudian dream world and colonialist psyches, Li's writing is haunted with ghosts and phantoms. His "Xungui ji" ("Seeking ghosts" - 1978) describes the narrator's "ghost-hunting" in the ghost-town of Zhutouqi, where the largest uprising of native inhabitants against the Japanese took place and many fallen martyrs lay. Rebuffing the existence of ghosts at first, he is visited by a ghost-like figure at his place of sojourn as forewarned. The ghost, reincarnating a historically factual name with multiple identities during the anti-Japanese struggle, and with its double still surviving, suggests a long continuum of such unrequited spirits in Taiwan history. The writer emerges from the experience with a renewed respect for the lingering disquiet of the dead, however scientifically unproven it may seem. ${ }^{21}$

20. Meigui meigui wo ai ni (Taipei: Yuanjin, 1984).

21. All three stories cited here are found in Li Qiao ji (Collected Works of Li Qiao) (Taipei: Qianwei, 1991). 
In another story, "Taimu Shan ji" ("The story of Mount Taimu"1984), Li mythologizes the legend of Lu Heruo, a writer of the colonial period who reportedly disappeared into the mountains in the aftermath of the 28 February repression and died of a poisonous snakebite. Describing the solidarity between the fugitive and the aborigines, who lead him through dangerous mountain paths to escape KMT capture, Li eulogizes the simplicity and grace of aboriginal worship of nature in contrast to the crassness and cruelty of mainland captors in hot pursuit. The conclusion is as affecting as Huang Chunming's story of rebirth: the dying hero, in a spirit of compassion, helps his captor slow the effect of snake poison; even after he is shot, he sprays seeds around himself and his captor so that where their bodies lie, trees would grow. (Mis)identifying himself variously as the historical anti-Japanese fighters Lin Shuangwen, Yu Shiji and $\mathrm{Yu}$ Qingfang to elude his captors, the overlapping of names with the story of Lu Heruo establishes a direct connection between Japanese invasion and KMT repression.

In yet another play on the interpenetration of dream and fiction, history and culture, Li juxtaposes a "factual" story with a dream ("Nielong ji," "Slaying dragons" - 1985). The fact, reported in Newsweek, pertains to a mainland Chinese father who in obedience to the government's one-child policy kills his four-year-old daughter to make way for a son. Pushing his daughter down a well and then "having peered down it to check if she was dead, he coolly lit a cigarette." The narrator, who is a writer, tries to devise ways of re-presenting the story in fiction form, yet in the end his imagination runs dry. How is it conceivable to "coolly light a cigarette" by a well in which a man has moments before drowned his daughter?

In the second part of the story, the writer dreams of a yellow dragon that terrorizes the earth by guzzling up prostrate men. The writer, unwilling to die such a meaningless death, resolutely takes up arms against the dragon, only to witness sprouting in its place two other dragons, one red and the other blue. The battle goes on interminably: each time a dragon is slain, others spring forth in exponential increments. The dream, a thinly veiled invective against Chinese despotism throughout the ages - from the mythical Yellow Emperor to the Communists and $\mathrm{Na}-$ tionalists - adumbrates the child-killing scene in the first part of the story. The devastating question it raises recalls Lu Xun's desperate cry: what can one do in the face of such a deeply rooted, vicious cannibalistic culture? "Save the children ..." 22

If the homeland described by Li Qiao is one rife with ghosts and demons, the garden that symbolizes Taiwan in the feminist Li Ang's (1952-) Miyuan (Bewildering Garden - 1991) is no less ill fated. It is a labyrinthine tale of the main character Zhu Yinghong's search for identity. Born after the war, the girl grows up in a garden elaborately adorned with pavilions, streams and poetry reminiscent of the famous garden in the 18th-century Chinese classic Honglou meng (Dream of Red Cham- 
ber). The main character's name, Yinghong (reflecting red), and the garden's, Han yuan (Chinese garden), are obvious puns intended to be understood intertextually. Like its antecedent Honglou meng, which ends with imperial disfavour and a calamitous raid, the Han garden is also haunted with past memories of Yinghong's father arrested in the wake of the 28 February Incident. Through the girl's mistaken collapse of time frames, confusing the Sino-Japanese War by which Taiwan was ceded to Japan (1895) and the year of the post-war KMT atrocities (1947), the two intertwined traumas become the originary curse over Taiwan intellectuals already embedded in a Chinese culture. The writer's idealization of the feminine, sinicized father and her laborious depiction of the garden convey a nostalgic attachment to a cultural Chinese past. Zhu Yinghong's subsequent self-abasement to men of an opposite cast - prosperous Taiwan businessmen with inexhaustible virility, one of whom invades her garden, marries her and promises to help her restore the garden to its former glory - reveals a grudging acceptance of the aggressive nouveau riche that exemplify present-day Taiwan. The writer's identification with the feminine refinement of Chinese culture of a bygone era must now give way to a masculinized, vulgarized and yet empowered Taiwan. Such allegorical intentions are overtly displayed: in the end, Yinghong donates the garden that had for two centuries belonged to the Zhu family - the name of the Ming dynasty - not to "any government that oppresses the people," but "to Taiwan, to all 20 million Taiwanese people." ${ }^{23}$ Her self-conscious disruption from history, however, is accompanied by waves of melancholic attachment and fatalistic resignation:

After dinner, Zhu Yinghong switched on the garden lights. All of a sudden Han Garden lit up the heavy, dark, empty environs, flooding it with brilliant artificial radiance. The upturned eaves, the meandering corridors, all exuded age-old warmth, a familiar beckoning from the veins. It was as if time had reversed its course, returning to the age of the Liao Zhai stories. ${ }^{24}$ Picture someone travelling in the dark of night, treading upon endless fields. Suddenly she came upon a huge mansion aglow with light. Not that she was gullible, but that warm glow seduced a primal desire for return. Were this a dream, a trap, one would still fall for it uncontrollably: the whole scenario was so warm, there was such an aura of fatality, an efflorescence of ultimate romanticism for which one would die ... She felt an urgent need to take another look at the garden, for fear it would disappear and everything that had happened would vanish as though it had never taken place, never ever existed (p. 277).

Like Bai Xianyong before her, Li Ang attempts to re-create the lost garden of Honglou meng that has become synonymous with Chinese culture, but fails. Ironically, that artistic failure boldly conceived demonstrates her fatalistic thesis that such an elegant time and place could never be replicated. Her project of resuscitating cultural memory is doomed by the very fact of a past already lost.

23. Miyuan (Lost Garden) (Taipei: Maitian, 1998), p. 276.

24. The Liao Zhai zhiyi (Strange Tales of the Idle Studio) (1766), a famous late 18thcentury collection of classical stories. 
The theme of perturbed confrontation between past/present, feminine/ masculine, eternal value/transitory pleasure finds bold new expression in another woman writer, Zhu Tianwen (1956-), who paints the contemporary skyline in extraordinary detail. Her urban scenes employ a bricolage of images that conveys the jarring incongruities of everyday life. In "Chai Shifu" ("Master Chai" - 1988), an ageing mainland emigre tries to earn a living in Taiwan by practising a combination of Buddhist teaching, traditional medicine and massage. The corner he occupies in his son's apartment papered with Daoist and Buddhist maxims adjoins a peepshow parlour his son owns. His transcendental ruminations take place in tandem with his granddaughters doing homework in front of a television set showing adult videotapes. Now a revered master of the mysterious art of massage, he dreams of returning to Kunming in old age but yearns for the touch of a young patient's breasts. In Zhu's own words, Taipei is an "exciting, wild place" where "the dead and the living, gods and ghosts, all occupy the same space and time." 25

In another story, "Shiji mo de huali" ("Fin-de-siècle splendour"1990), the scrappiness of the Taipei skyline poses a striking contrast to the beauty that the main character, Mia, can create out of shreds and fragments. A former model whose personae change as readily as fads and fashions, she inhabits a space where all forms of human activity and feelings are concentrated, mixed and blurred. Sitting, eating, drinking, dancing and sleeping all take place in the same room, or else outdoors in the car. Her world is one of virtual reality, constituted by popular music, drugs and an overabundance of fabrics, bath salts, oils and fragrances. Madonna, the material woman, is her generation's paradigm. Indeed, Mia's exuberant life-style makes extravagance out of necessity, luxuriating in hybridity. The story is a carnivalesque celebration of material objects and exaggerated (non)identities, a decadent, fin-de-siècle abandonment to self-delusion. This, in the author's words, is the younger generation's feminist answer: "She knows that one day the world built by men's theories and systems will fall, but she will survive with 'the memory of smell and colour,' and thence rebuild the world." 26

In this post-modern admixture of voices and images, it is the aborigines who in the 1980s and 1990s step forth to claim authenticity and originariness to a Taiwan identity. The images they use in their writings are telling: instead of the garden that must be grown and the soil that must be tilled, the aborigine writers speak of the magic of nature: the mountains, rivers, and forests:

If only our fattening officials would come up the mountains to explore the forest's secrets ... if only they would listen in solitude to the birds, the wind, the beasts, and the falling leaves, and then, wandering into the valleys, look up at the majestic cliffs; if only they would take off their shoes and step into the clear streams ... they would take in the mystery that is the forest. ${ }^{27}$

25. Shiji mo de huali (Taipei: Sansan, 1990), p. 27.

26. Ibid. p. 192

27. Tian Yage, Zuihou de lieren (The Last Hunter) (Taichung: Chenxin, 1987), p. 66. 
Faced with an endangered way of life, the aborigine consciousness, according to Sun Dacun, must be reconciled with "going gently into the night." 28 It is this last image that encapsulates the saddest awakening of a native consciousness of all.

\section{Conclusion}

Tracing the development of a native consciousness through images in literature, one must be aware of the pitfalls of such a vastly simplified genealogy. To contextualize every literary event would go far beyond the scope of an article; to condense a tumultuous century into a few images would give an impression either of fixity or of unilinear, teleological progression. I have, however, tried to recapture some of the enduring images with which literature seeks to describe consciousness. My choice of subject matter, which is one of consciousness of place, necessarily privileges texts closer to "home," excluding many other forms of experimentation in language, style, ideological complications and thematic content. For example, much of modernist poetry, feminist writing, science fiction and diasporic writing, as well as theoretical and historical explorations of nation and identity, deserve separate studies. Neither is literature alone in the momentous movement towards constructing a native consciousness. The recent democratization of cultural production in the spheres of art, media, film, literature, drama, music, dance, monument building and naming, and museum collection and display has given rise to multiple sites of ideological contestation and diverse modes of consciousness-building. Unprecedented public debates on what gets presented, sponsored, published, anthologized, circulated, marketed and canonized reveals both the intricacies of the normative process of nationbuilding, as well as the existing momentum towards cultural democratization. In the world of book publishing, wealth accumulation has resulted in a market that has surprising capacity for sustaining a large variety of genres, including publishers devoted to serious books on every aspect of Taiwan history and society and to nurturing local talent.

In retrospect, it is surprising how good literature does survive and thrive in spite of the tyranny of political clamour, in Taiwan and elsewhere. As we stand at the end of a century of struggle for recognition of a Taiwan presence, we must be prepared to answer the question: what constitutes a Taiwan consciousness? Such nativity was never a fixed or uniformly accepted entity. Initially defined against Japanese colonization

28. Jiujiu jiu yici (Getting Drunk Once in a Long While) (Taipei: Zhang laoshi, 1991), p. 118. For discussions on Taiwan literature and the "localization movement," see Chen Zhaoying, Taiwan wenxue yu bentuhua yundong (Taiwan Literature and the Localization Movement) (Taipei: Zhengzhong, 1998); You Shengguan, Taiwan wenxue bentu lun de xingqi yu fazhan (Rise and Development of Taiwan Literary Localism) (Taipei: Qianwei, 1996); Chen Yingzhen, "Taidu pipan de rogan lilun wenti" ("Some theoretical problems of Taiwan Independence critique"), Haixia pinlun (Straits Commentary), April 1995; and Chen Fangming, "Zhimin lishi yu Taiwan wenxue yanjiu" ("Colonial history and Taiwan literary studies"), Zhongwai wenxue (Literature Chinese and non-Chinese), Vol. 23 No. 12 (1995), pp. 110-19. 
in various shades of assimilation and resistance, it came to be defined along different axes in chains of signification amidst changing historical contexts: against Western values (capitalist/imperialist/materialist/ decadent); against the KMT (mainlander minority rule/return to China myth/repression); against mainland Chinese socio-political reality (regressive/oppressive/economically and socially backward); against the combined KMT-CCP big-China chauvinism; against Han repression of aborigines; against traditional patriarchy, and so on. Hence to those engaged in rewriting its history and envisaging its future, "Taiwan" has come to signify many things apart from a geopolitical location of identity. It is a varied, multifaceted notion that contains diverse ingredients of progress, autonomy, free expression and democracy, all imbued with a belated compensatory passion. From subjugation, bewilderment and loss, Taiwan's self-image has now been replaced by a self-congratulatory, if make-shift, hybrid one. Indeed, the images of Wu Zhuoliu's orphan and Yang Kui's lone raised head, of Lu Heruo's and Wang Zhenhe's oxcart and Bai Xianyong's lost paradise must now yield to fragmentary images of a city skyline at odds with itself.

Whether the image of the sorrowful native at once proud and humble that fired the cultural imagination will endure into the next century as an emotive emblem is of course debatable. Already transnationalization of cultural production and travelling texts are blurring borders. Increasingly writers on the mainland publish in Taiwan or Hong Kong and vice versa, and writers out of vogue in Taiwan or the mainland will find an enthusiastic audience on another shore. Migration, travel, inter-marriage and cyber-space communication, as in the past but at a more frenzied pace than ever, should in theory render many of the territorial concerns of nativity irrelevant. Who can claim authenticity to a migrant society now become increasingly mobile? In an era of dislocation, when marginality has become a position of privilege, is location and nativity still a burning issue? Is Taiwan also in danger of becoming a hegemonic discourse, thus suppressing other voices within? With the threat of violence to achieve nationalistic goals looming over economic and cultural traffic, it is apt that we revisit the distinct texts that make up a communal psyche with an awareness of the pitfalls all such endeavours may entail. 